\title{
Intranasal Delivery and Transfection of mRNA Therapeutics in the Brain Using Cationic Liposomes
}

Harkiranpreet Kaur Dhaliwal $^{1}$, Yingfang Fan ${ }^{1}$, Jonghan Kim, Mansoor M. Amiji*

Department of Pharmaceutical Sciences, School of Pharmacy, Bouve College of Health Sciences, Northeastern University, Boston, MA 02115, USA

\section{SUPPLEMENTARY INFORMATION}

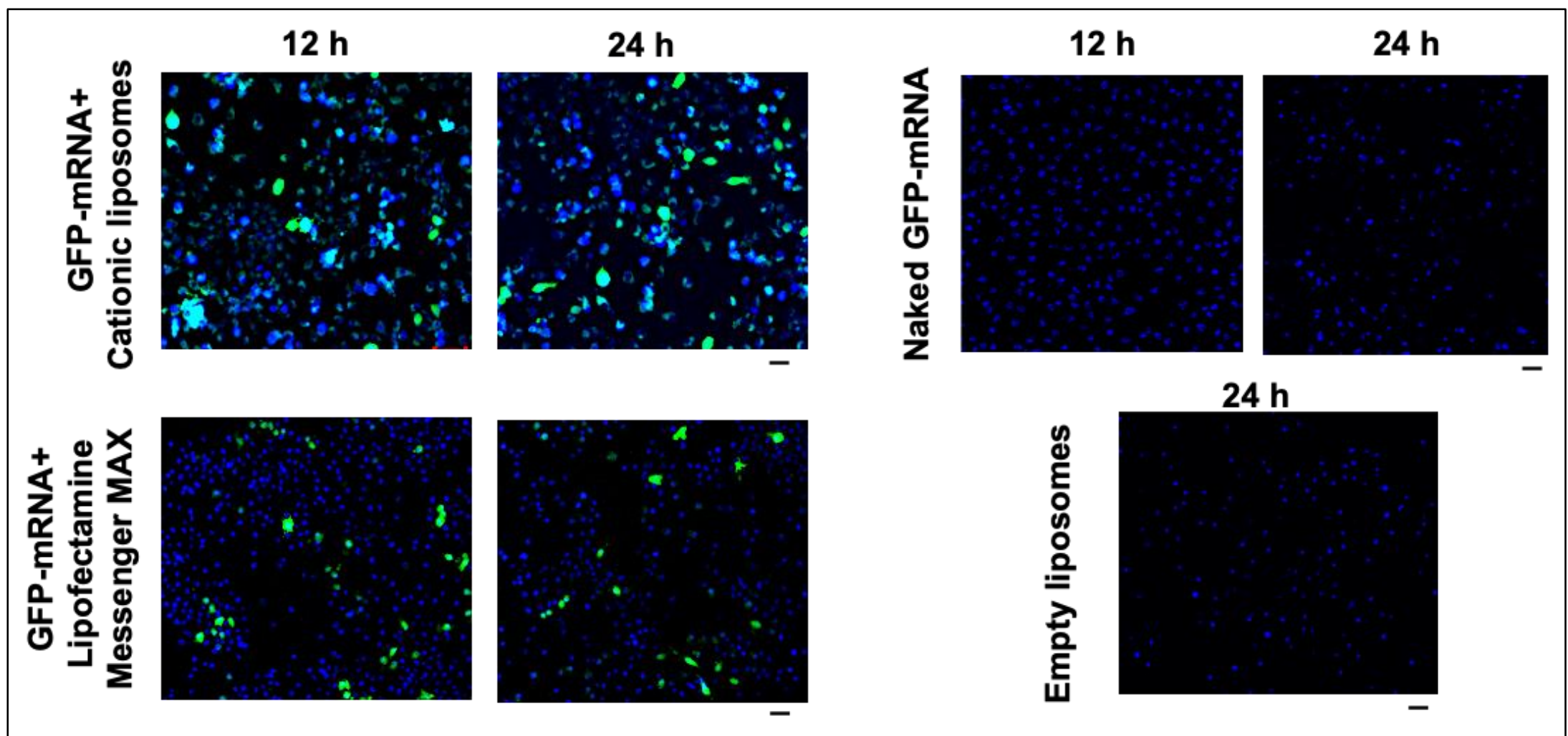

Supplementary Figure S1. Green Fluorescent Protein (GFP) mRNA transfection in J774A.1 macrophages using cationic liposomes at 12 and $24 \mathrm{~h}$ post-incubation time points. GFP-mRNA ( $5 \mu \mathrm{g})$ was administered per 200,000 cells via cationic liposomes, and Lipofectamine MessengerMAX (positive control), respectively. Empty liposomes were used as negative control. The GFP expression was imaged at 12 and $24 \mathrm{~h}$ post-transfection of GFP-mRNA using confocal microscope. Naked GFP-mRNA group did not show mRNA expression. Lipofectamine and liposome loaded mRNA groups showed GFP expression at both 12 and 24 h time points. Green: GFP, Blue: Nucleus. Scale Bar: $50 \mu \mathrm{m}$. 




Supplementary Figure S2. Green Fluorescent Protein (GFP) mRNA expression in mouse brain, 48 h post-intranasal administration of GFP-mRNA loaded cationic liposomes. Mice were intranasally administered with vehicle (empty liposomes), naked GFP-mRNA (3 mg/kg), and GFP-mRNA/Lipo (3 mg/kg). Mouse brains were imaged using IVIS $48 \mathrm{~h}$ post-administration, where GFP-mRNA/Lipo group did not show significant GFP signal compared with either vehicle or naked GFP-mRNA group. $\mathrm{N}=3$ /group. 